\title{
Analysis of components of self-ignition engine exhaust gases powered with biofuels
}

\author{
Marietta Markiewicz ${ }^{1 *}$,Jan Gutsche ${ }^{1}$, Adam Talaśka ${ }^{1}$, Anna Dzioba ${ }^{2}$ \\ ${ }^{1}$ Bydgoszcz University of Science and Technology, Faculty of Mechanical Engineering, Al. prof. S. \\ Kaliskiego 7, 85-796 Bydgoszcz, Poland; \\ ${ }^{2}$ Cuiavian Univercity in Wloclawek, Faculty of Social and Technical Sciences, ul. Okrzei 94A, 87- \\ 800 Wloclawek, Poland.
}

\begin{abstract}
Ecological approach to transport including the fuel which is used in combustion engines involves a necessity of alternative solution application. The study shows test result analysis of the amount of exhaust gases affecting natural environment. The tests were performed for a $81 \mathrm{~W}$ self-ignition engine with a direct fuel injection. The experiment was conducted for a fuel mixture containing $70 \%$ of diesel oil $30 \%$ of fatty acid methyl esters. The results regarding concentration of fuel components obtained for the analyzed mixture were compared with the results obtained for a diesel oil without fatty acid methyl esters. Based on the analysis, it can be said that $30 \%$ additive of fatty acid methyl esters to diesel oil is not enough to decrease the amount of harmful substance emission to the atmosphere by a power unit.
\end{abstract}

\section{Introduction}

Petroleum which a mixture of carbohydrates, carboxylic acids, thioalcohols, heterocyclic nitric compounds, phenols, thiophen derivatives, resins and metalorganic compounds undergoes constant technological modifications for purification and separation of chemical compounds and their refinement [1]. Diesel oil which is injected by means of the power supply system to the engine combustion chamber must be characterized by such properties as: density, viscosity, water content, low temperature properties, volatility, calorific properties and octane number [2]. The fuel used in self ignition engines must quickly evaporate and mix with the air forming a mixture ready to self-ignite due to a short time of the mixture preparation. [3]. Biodiesel is an alternative to oil derived fuels. It is produced from renewable resources and considered to be an alternative fuel for self-ignition engines. Biodiesel is a biodegradable and non-toxic fuel and its application significantly decreases emission of harmful substances into the atmosphere. It can be used everywhere diesel oil is used. [4]. Mixtures of pure fatty acid methyl esters FAME with a diesel referred to as biodiesel are supposed to provide the engine with good conditions of operation. It needs to

\footnotetext{
* Corresponding author: marmar000@pbs.edu.pl
} 
be noted, however, that application of biodiesel causes a $20 \%$ increase in the content of nitric oxide to be released to the atmosphere [5].

In 2016 emission of toxic substances into the environment caused by the European Union transportation increased by $0.7 \%$ as compared to earlier years. In Poland, the emission increased by $1.6 \%$ as compared to the previous year. The share of $\mathrm{CO} 2$ emission in member states of the EU in 2016 is presented in figure 1.

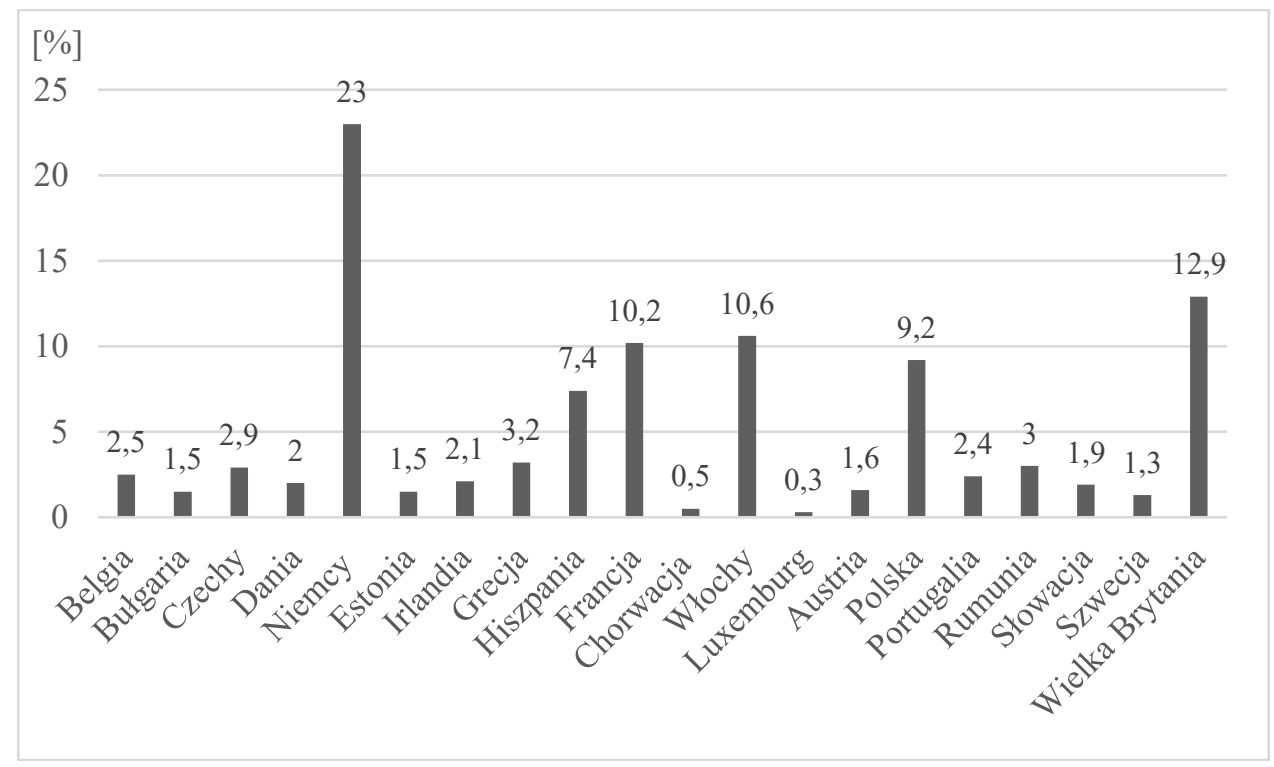

Fig. 1. Share of CO2 emission in the EU countries in 2016 [6].

The powertrain of motor vehicles is a piston combustion engine where chemical energy is converted into mechanical energy. Combustion engines are usually powered with hydrocarbon fuels whose burning involves rapid oxidation. Combustion of fuels is accompanied with formation of chemical compounds in the exhaust gases which can be divided into toxic and nontoxic. Toxic components include: carbon oxide, hydrocarbons, nitric oxides, soot, sulfur oxides, lead compounds whereas nontoxic fuel components include: carbon dioxide, water vapor, oxygen and nitrogen. Self-ignition engine provides power to 5 million vehicles registered in Poland, including passenger cars and heavy duty vehicles. The number of criteria to be used for self-ignition engine fueling, makes it difficult to select the best concept for fueling this type of engines. Literature also provides examples of parameter analyses for other transport means [7].

Tests of the major performance parameters of self-ignition engines fueled with plant oil or a mixture of a plant oil with diesel oil are conducted in many domestic and foreign research centers. Analyses of tests found in literature are concerned with application of plant oil as an engine fuel $[8,9,10,11]$. Literature provides an array of fuel consumption tests, whose authors report an increase in fuel demand when self-ignition engines are fueled with mixtures of diesel oil and fatty acid methyl esters. [12, 13, 14, 15]. Fuel combustion increases by app. $18 \%$ as compared to pure diesel oil for application of $35 \%$ fatty acid methyl ester additive [16]. Application of fatty acid methyl esters in combustion engines causes reduction in toxic pollution emissions, such as carbon oxides, hydrocarbons and solid particles $[17,18$, $19,20,21,22,23,24,25,26,27,28]$. Nitric oxides are an exception as their amount increases by several percent as compared to pure diesel oil [29].

The aim of this study is to verify the amount of fuel components of a given power unit which was fueled with a mixture of diesel oil and fatty acid methyl esters. The tests were 
conducted for verification of the possibilities of improving the performance parameter values of these units when using an alternative fuel. Literature provides different methods for transport system functioning assessment [30, 31, 32].

\section{Test material and methodology}

The tests involved assessment of performance parameter values of a power unit fueled with diesel oil and fatty acid methyl ester additives. Apart from diesel oil, the material used for the tests was a plant oil subjected to transesterification, that is, an exchange of glycerine chemically bonded in a triacyloglicerole particle for added methyl alcohol in the presence of an alkaline or acidic catalyst, which are commonly referred to as a biocomponent. Figure 2 shows a mixture composed of $70 \%$ of diesel oil and $30 \%$ of fatty acid methyl esters which was used for the tests. In literature there are examples of physicochemical tests of a working fluid including the analyzed fuel [33].

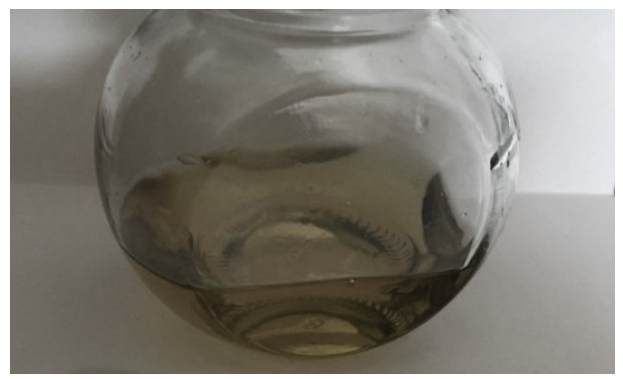

Fig. 2. Mixture of $70 \%$ diesel oil and $30 \%$ fatty acid methyl esters .

The research object was a self-ignition engine used in car transportation means. The power unit was selected due to the fact that it is commonly used in car transportation. The test engine was a self-ignition engine of maximal power $81 \mathrm{~kW}$. This engine is characterized by Common Rail direct fuel injection with electromagnetic injectors. The tested engine is presented in figure 3 . The power unit collaborates with a two mass flywheel and a turbo charger of variable blade geometry which is used to improve the engine performance. The engine was equipped with a solid particle filter.

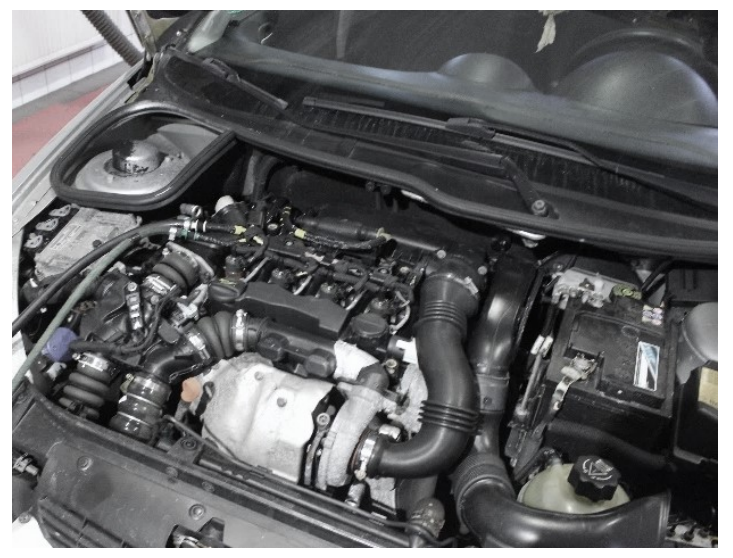

Fig. 3. Power unit used in tests.

The supply pump sucked the fuel mixture from the fuel tank which flowed through a prefilter. Then the fuel was pumped into a fine filter. From the fine filter the fuel was supplied to the supply chamber of Common Rail high pressure system and to electromagnetic injectors 
through injection pipes on the engine head. Electronically controlled injector adjusted the injection start and the amount of fuel dose. The mixture was injected directly to the turbulence chamber. The mixture dose was sprayed inside the cylinder working space and mixed with sucked air. Standard filters designed for this engine model were used during supplying the engine with mixtures of diesel oil and fatty acid methyl esters.

The experiment was carried out in order to determine the engine performance parameters for a given mixture of diesel oil and fatty acid methyl esters and for standard settings of the power unit. Road conditions were simulated during the tests. The process was interfered with in a planned manner.

The task was to provide assessment of the composition of exhaust gases and the concentration of solid particles. The tests of an engine fueled with fatty acid methyl esters and diesel oil were conducted with the use of a chassis dynamometer with an eddy current brake. The measurement was affected by air humidity, atmospheric pressure changes and air temperature whose values are normalized. The measurement of toxic components of exhaust gases was performed by means of an exhaust gas analyzer MGT-5, which along with a measurement probe, had certificates of periodic verification. The analysis of exhaust gases made it possible to define the amount of exhaust components that are released to the atmosphere in the form of gases. The above described device is designed for measuring the toxicity degree of self-ignition vehicles and used for determination of values of such compounds as: hydrocarbons $(\mathrm{HC})$, oxygen $(\mathrm{O} 2)$, carbon oxide $(\mathrm{CO})$, carbon dioxide $(\mathrm{CO} 2)$, nitric oxides (NO2). In combustion engines, it is the exhaust system that is responsible for emission of pollutants to the environment. The value of exhaust gas component concentration depends on the engine design, operation conditions, and the kind of fuel. Formation of carbon oxide is caused by shortage of oxygen during the process of combustion and originates in the engine chamber. The level of carbon oxide content in exhaust gases depends on the composition of the fuel mixture [34]. Nitrogen oxides occur in the exhaust gases in result of the combustion temperature. These substances are produced in the engine combustion chamber due to oxidation of atmospheric nitrogen [35]. High value of nitric oxides is caused by premature combustion of the mixture. Occurrence of hydrocarbons during fuel combustion in a self-injection engine is caused by oxygen shortage or breaks in the ignition system operation [36]. The amount of hydrocarbons getting to the atmosphere depends on the fuel mixture composition. Measurement of emission of solid particles with dimensions exceeding $100 \mathrm{~mm}$, was performed with the use of MPM-4 analyzer of Maha company. Measurement of solid particles contained in the exhaust gases was performed by the optical method. This method involves measuring intensity of the light beam which goes through the stream of exhaust gases, that is, comparison of infrared adsorption between a model neutral gas and the analyzed compound [37]. Solid particles that occur during fuel combustion in self ignition engines are particles of carbon and smaller particle absorbed by it, that is, soot. The value of solid particles emitted during fuel combustion was calculated from statistical values. Distribution of the solid particle sizes and their number, were determined with the use of an electronic particle counter. Although literature provides results of research on similar units, the authors of this study find it advisable to present results of tests of selected performance parameters of a combustion engine [38, 39, 40].

\section{Test results}

The tests were performed for a mixture of $70 \%$ diesel oil and $30 \%$ fatty acid methyl esters. The tests were conducted in a laboratory environment for six performance parameters of the power unit. The test results are presented in table 1 including a basic statistical analysis 
depicting standard deviation, variability coefficient and the minimum and maximum for a given measurement. Each measurement was repeated 30 times.

Table 1. Results of performance parameter tests of a power unit for mixture of $70 \%$ diesel oil and $30 \%$ fatty acid methyl esters.

\begin{tabular}{|c|c|c|c|c|c|c|}
\hline & 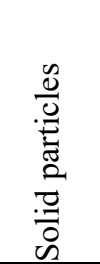 & 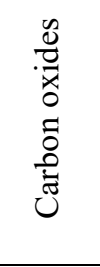 & 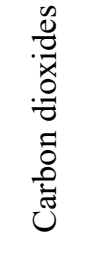 & $\begin{array}{l}\text { D̃ } \\
\text { on } \\
\widehat{\widehat{x}} \\
0\end{array}$ & 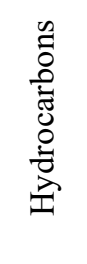 & 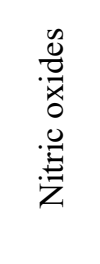 \\
\hline average $[\mathrm{KM}]$ & 75.03 & 0.068 & 1.88 & 10.25 & 9.03 & 237.77 \\
\hline median & 75.5 & 0.04 & 9.0 & 9.98 & 9.0 & 236.5 \\
\hline Standard deviation & 4.468 & 0.065 & 0.325 & 2.069 & 0.546 & 16.132 \\
\hline Variability coefficient & 0.06 & 0.957 & 0.027 & 0.202 & 0.06 & 0.068 \\
\hline minimum $[\mathrm{KM}]$ & 68.0 & 0.04 & 11.3 & 6.96 & 8.0 & 107.0 \\
\hline $\operatorname{maximum}[\mathrm{KM}]$ & 85.0 & 0.28 & 12.2 & 18.98 & 10.0 & 283.0 \\
\hline
\end{tabular}

Table 2 shows components of exhaust gases for pure diesel oil with no fatty acid methyl ester additives. The test environment and the power unit have not been changed.

Table 2. Results of tests of the power unit performance parameters for diesel oil with no fatty acid methyl ester additives.

\begin{tabular}{|c|c|c|c|c|c|c|}
\hline & 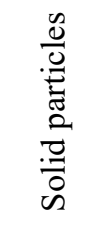 & 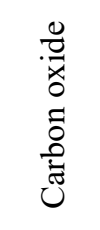 & 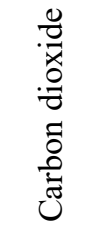 & 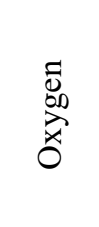 & 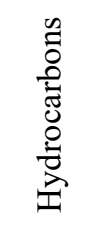 & 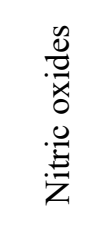 \\
\hline average [KM] & 94.0 & 0.13 & 11.96 & 17.29 & 51.47 & 227.23 \\
\hline median & 94.0 & 0.11 & 12.0 & 17.09 & 43.9 & 227.5 \\
\hline standard deviation & 2.607 & 0.071 & 0.384 & 0.694 & 19.94 & 12.983 \\
\hline Variability coefficient & 0.028 & 0.546 & 0.032 & 0.04 & 0.387 & 0.057 \\
\hline minimum $[\mathrm{KM}]$ & 87.0 & 0.04 & 11.2 & 16.21 & 30.0 & 196.0 \\
\hline maximum $[\mathrm{KM}]$ & 97.0 & 0.43 & 12.9 & 18.47 & 88.0 & 251.0 \\
\hline
\end{tabular}

The tests results allowed to find out whether application of fatty acid methyl ester additives in diesel oil is advisable or not. Comparison of the analysed components of exhaust gases with the base fuel that is, diesel oil, is presented in figures 4-9. 


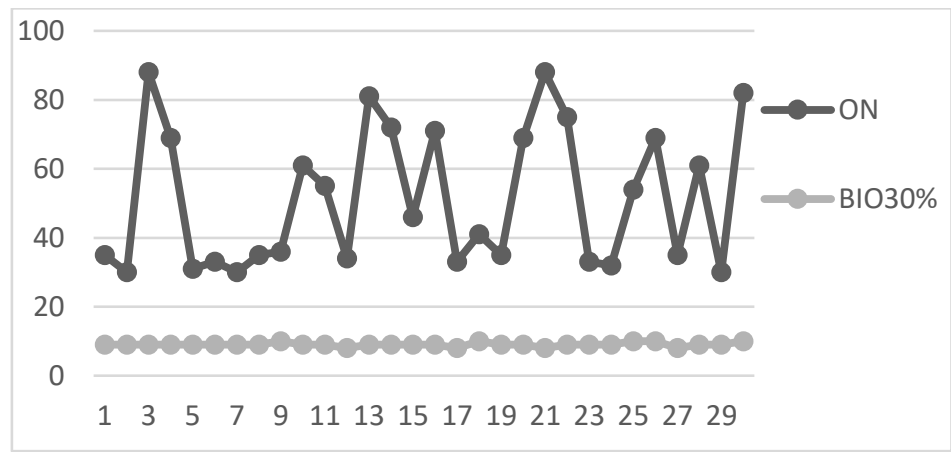

Fig. 4. Comparison of the amount of solid particles in the analyzed mixtures.

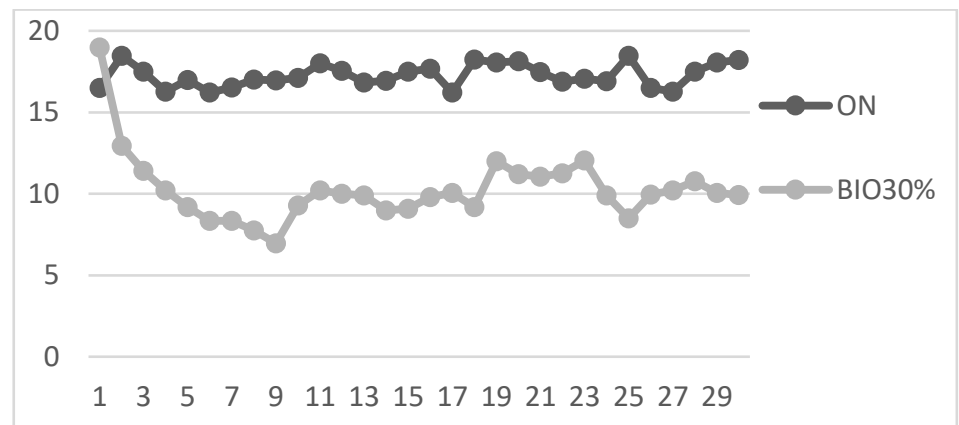

Fig. 5. Comparison of the amount of oxygen in the analyzed mixtures.

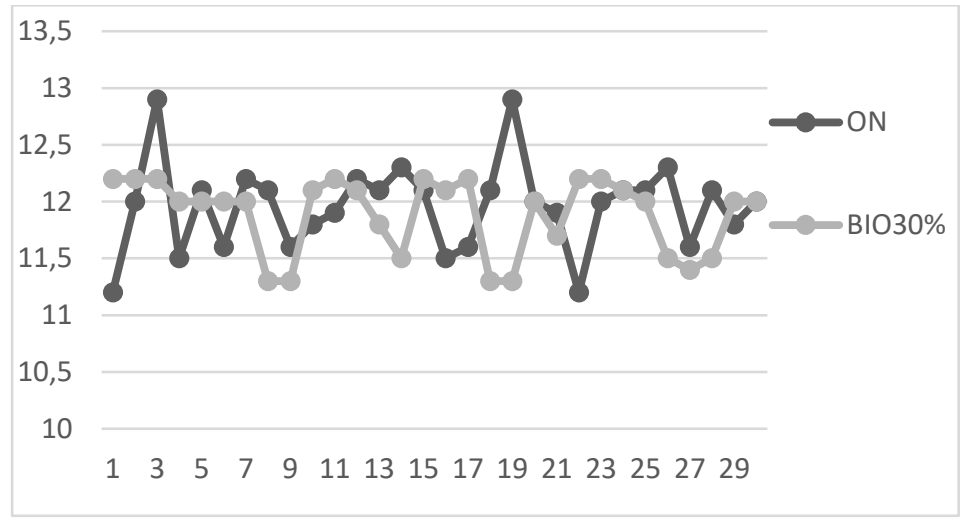

Fig. 6. Comparison of the amount of carbon dioxide in the analyzed mixtures. 


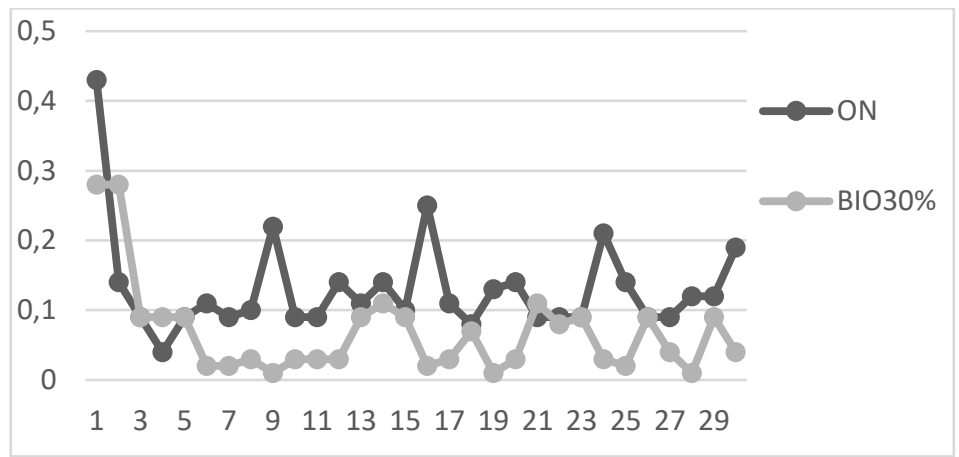

Fig. 7. Comparison of the amount of carbon oxide in the analyzed mixtures.

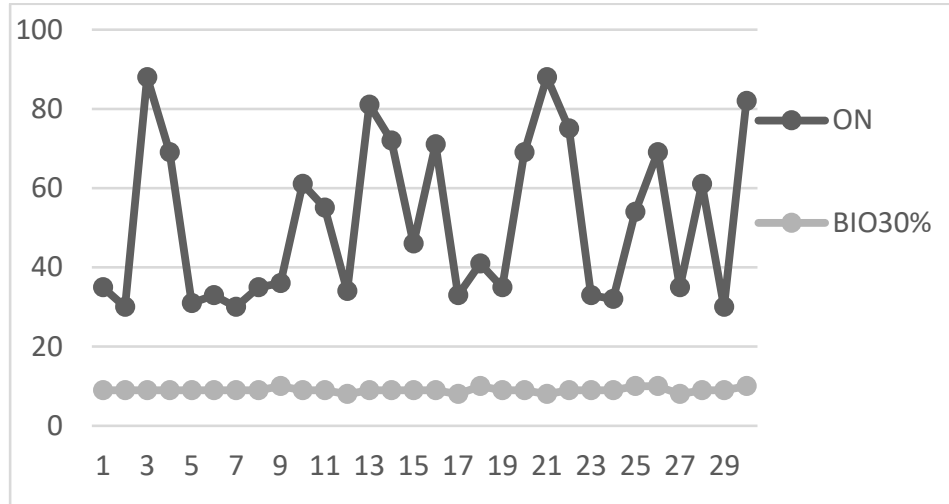

Fig. 8. Comparison of the amount of hydrocarbons in the analyzed mixtures.

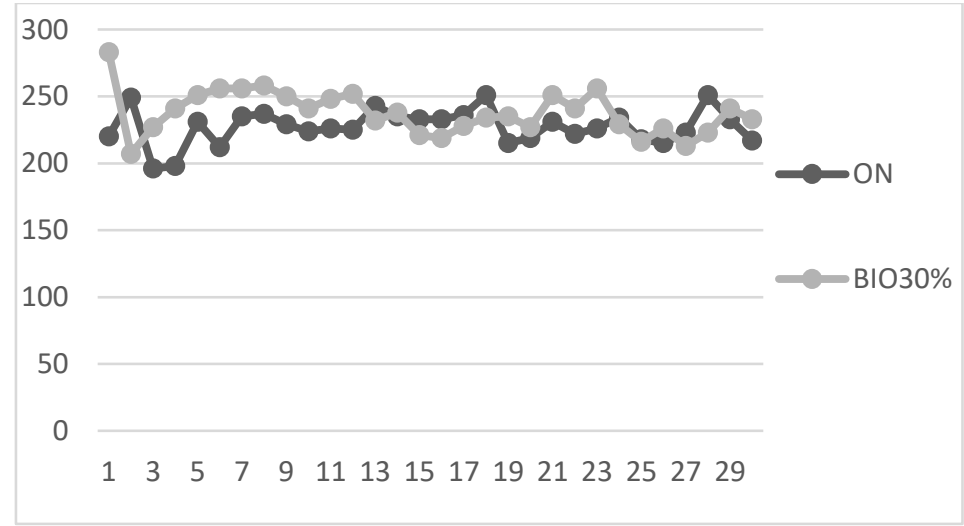

Fig. 9. Comparison of the amount of nitric oxides in the analyzed mixtures.

The data presented in the charts shows a comparison of fuel mixtures: diesel oil with no fatty acid methyl esters and $70 \%$ diesel oil and $30 \%$ fatty acid methyl esters. The lowest parameters for the mixture of $70 \%$ diesel fuel and $30 \%$ fatty acid methyl esters were found for solid particles and hydrocarbons. The amounts of nitric oxides and carbon dioxide in exhaust gases were at the same level. The results indicate too small content of fatty acid methyl esters in diesel oil. 


\section{Conclusion}

Environment protection and reduction in the emission of exhaust gas toxic components into the atmosphere involve a necessity to seek alternative solutions for self-ignition engine fueling. This work presents partial results of tests for one mixture, that is, $70 \%$ diesel oil and $30 \%$ fatty acid methyl esters. Based on the results, it can be said that the $30 \%$ share of fatty acid methyl esters in diesel oil is not enough to reach satisfying results. The analyzed parameters have a significant influence on the natural environment, though not all of them have a negative effect. The most important parameters which can be considered as toxic are carbon dioxide and nitric oxides. In the case of these parameters, no improvement, that is, amount reduction, was reported for the power unit fueled with the mixture alternative to diesel oil. Reduction in the amount of exhaust components was found for carbon dioxide, oxygen and hydrocarbons. A significant decrease could be also observed for solid particles whose amount has also an impact on the environment. When analyzing all the results obtained for all the studied parameters it can be said that $30 \%$ additive of fatty acid methyl esters to diesel oil is insufficient to reduce the amount of fuel components down to the amount which is comparable with other power units considered to be ecological.

\section{References}

1. D. Bociarska D., Technology of petroleum in Lotos s.a. group (2007)

2. P. Zając, Engines of automobiles, Wydawnictwo Komunikacji i Łączności, Warszawa (2009)

P. Droździel, Spectrum of self-ignition engine start as a criterion for assessment of a car use, Polish Operational and Systems Research Society, Warszawa (2009)

3. M. Baraniak, T. Łaczek, Low temperature of biofuels containing fatty acid methyl esters from animal fat processing, Nafta- Gaz (2010)

4. M., Markiewicz-Patalon, J. Kaszkowiak, Assessment of Purposefulness of the Premium Type Diesel Fuels' Use In Reducing the Unfavourable Influence On the Environment, Journal of Research and Applications in Agricultural Engineering, No 3/62 (2017)

5. www.ec.europa.eu

6. Central Statistical Office, international statistics, international comparisons, information tables, use of petroleum (2016)

7. L. Knopik, K. Migawa, P. Kolber, Statistical analysis of parameters of rail vehicles, 22nd International Conference on Engineering Mechanics, 9-12 May 2016, Svratka, Czech Republic (2016)

8. M. Idzior, J. Merkisz, Rape oil as ecological - energy alternative to high pressure engine fuels. Alternative fuels for combustion engines, IBMER, Warszawa (1993)

9. Z. Kiernicki, P. Szczęsny, Tests of high pressure engine powered with biofuel based on rape oil, Jurnal of Kones, Lublin (1994)

10. W. Lotko, Fueling combustion engines with alternative fiuels, Ed. Office of Higher Engineering School and Maintenance Technology Institute in Radom (1995)

11. W. Lotko, R. Longwic, Undetermined states of an engine powered with rape oil, Ed. Radom university of technology, Radom (1991)

12. A. Podolak, I. Petransky, A. Zikla, J. Finorowa, Prewadzkove a ekologicke vlastnosti biopaliw z repky ozimnej, Acta Technologica Agriculturae, Slovaca Universitas Agriculturae Nitriae (1998) 
13. A. Demirbas, Importance of biodiesel as transportation fuel, Energy Policy, Volume 35 (2007)

14. G. Fontaras, G. Karavalakis, M. Kousoulidou, T. Tzamkiozis, L. Ntziachristos, E. Bakeas, S. Stournas, Z. Samaras, Effects of biodiesel on passenger car fuel consumption, regulated and non-regulated pollutant emissions over legislated and realworld driving cycles, Fuel, Volume 88 (2009)

15. H. Halleux, S. Lassaux, R. Renzoni, A. Germain, Comparative Life Cycle Assessment of Two Biofuels Ethanol from Sugar Beet and Rapeseed Methyl Ester, Wood and Other Renewable Resources, Vol 13 (2008)

16. G. Labeckas, S. Slavinska, The effect of rapeseed oil methyl ester on direct injection Diesel engine performance and exhaust emissions, Energy Conversion and Management, Volume 47 (2006)

17. Law of 25 August 2006 on biocomponents and liquid biofuels (Journal of laws 2006 no 169 pos. 1199)

18. B. Bala, Studies on biodiesels from transformation of vegetable oils for diesel engines, Energy Edu Sci Technol (2005)

19. S. Choi, Y. Oh, The emission effects by the use of biodiesel fuel, International Journal of Modern Physics B., Vol. 20 (2006)

20. G. Dzieniszewski, Selected aspects of ecological and economic of diesel engine fueling with plant fuel, Agricultural engineering, no. 6 (2009)

21. G. Fontaras, G. Karavalakis, M. Kousoulidou, T. Tzamkiozis, L. Ntziachristos, E. Bakeas,S. Stournas, Z. Samaras, Effects of biodiesel on passenger car fuel consumption, regulated and non-regulated pollutant emissions over legislated and realworld driving cycles, Fuel, Volume 88 (2009)

22. Knothe G., Sharp C., Ryan T., 2006, Exhaust emission of biodiesel, petrodiesel, neat methyl esters and alkanes in a new technology engine, Energy and Fuels, Vol. 20

23. Lapuerta M., Armas O., Rodriguez-Fernandez L., 2008, Effect of biodiesel fuels on diesel engine emission, Progress in Energy and Combstion Science, Vol.34

24. Leung D., Luo Y., Chan T., 2006, Optimization of exhaust emission of a diesel engine fuelled with biodiesel, Energy and Fuels, Vol. 20

25. Muślewski M., Markiewicz M., Pająk M., Kałaczyński T., Kolar D., Analysis of the Use of Fatty Acid Methyl Esters as an Additive to Diesel Fuel for Internal Combustion Engines, Energies, vol. 14 (2021)

26. Markiewicz M, Muślewski Ł,, Pająk M., Impact of Biocomponent Additive to Diesel Oil on Values of Selected Functional Parameters of Transport Means, Polish Journal of Environmental Studies, vol. 5 (2020)

27. Markiewicz M., Muślewski Ł., Survey performance and emission parameters of diesel engine powered by diesel oil and fatty acid methyl esters using fuzzy logic techniques, Fuel, vol. 277 (2020)

28. Markiewicz M., Muślewski Ł., The Impact of Powering an Engine with Fuels from Renewable Energy Sources including its Software Modification on a Drive Unit Performance Parameters, Sustainability, vol. 11 (2019)

29. Merkisz J., Kozak M., 2003, Wpływ składu mieszanek biopaliw z paliwami konwencjonalnymi na emisję toksycznych składników spalin, Eksploatacja i Niezawodność, nr 3 
30. A. Sołtysiak, K. Migawa, Application of the Pareto front for risk control in the transport system, 18th International Conference Diagnostic of Machines and Vehicles, 12.12.2019 Bydgoszcz, Poland, MATEC Web of Conferences, vol. 302 (2019)

31. K. Migawa, A. Sołtysiak, M. Czyżewska, Method of assessment of the transport system functioning with the application of the simulation model of the operating process, 18th International Conference Diagnostic of Machines and Vehicles, 12.12.2019 Bydgoszcz, Poland, MATEC Web of Conferences, vol. 302 (2019)

32. B. Landowski, M. Baran, Analysis of selected results of engine oil tests, MATEC Web of Conferences 302, 01010 (2019), 18th International Conference Diagnostics of Machines and Vehicles, pp.1-7 (2019)

33. Muslewski, L., Kulis, E., Landowski, B., Model of the process of operating rail transport means, Engineering Mechanics 2020 (IM2020) Book Series Engineering Mechanics (2020)

34. Mazanek A., 2010, Comparative tests of exhaust gases toxic components of self-ignition fueled with ON (diesel oil) and BIO10, Nafta-Gaz, nr 66

35. Kralik M., Jablonicky J., Nikolov M., 2015, Monitoring of NOx emission at selected diesel engine, University of Ruse „Angel Kanchev”, Agrarian and Industrial Faculty

36. Osipowicz T., Stoeck T., 2014, Wpływ oleju rzepakowego jako dodatku do paliwa na emisję substancji toksycznych do atmosfery przez silnik ZS, Autobusy

37. Peterson C., Toberski J., Thompson J., Chase C., 2000, The effect of biodiesel feedstock on regulated emission in chassis dynamometer tests of a pickup truck, American Society of Agricultural of Biological Engineering, vol 43(6)

38. Kalaczynski T.; Martynyuk V.; Boiko J.; Matyukh S.; Petrashchuk S.: Exploitation aspects of diagnostic hydraulic and pneumatic systems of Multimedia Hybrid Mobile Stages, Published 2021, 19th International conference diagnostics of machines and vehicles hybrid multimedia mobile stage

39. B. Żółtowski, M. Żółtowski, M. Łukasiewicz, Statistical research space of measures of vibration energy in machines, , Engineering Mechanics 2018, : Institute of Theoretical and Applied Mechanics of the Cech Academy of Sciences, p-ISBN: 978-80-86246-8882018, Svratka, Czech Republic (2018)

40. M. Łukasiewicz, T. Kałaczyński, J. Musiał, J.Shalapko. Diagnostics of buggy vehicle transmission gearbox technical state based on modal vibrations, Journal of Vibroengineering, 16, Issue 6

41. B. Landowski, Application of Markov decision process as a mathematical model of operation and maintenance process. p-ISSN: 1733-8670. Scientific Journals. Maritime University of Szczecin, 2010, 24(96) pp. 12-16 (2010) 